\title{
Monitoring of Fluoride Concentration in Karera and Narwar Blocks of Shivpuri District, India: Correlation with Physicochemical Parameters
}

\author{
Dr Meena Mourya \\ AP Sagar Institute of Research Technology and Science, Bhopal \\ Dr Manisha Sonel \\ AP Corporate Institute of Science and Technology, Bhopal
}

\begin{abstract}
Fluoride concentration in ground water samples was determined in 10 villages of Shivpuri district, M.P., India. 30 samples were collected and analysed for fluoride content along with $\mathbf{p H}$, electrical conductivity, total dissolved solids (TDS), total hardness, total alkalinity, chlorides, magnesium, nitrates and iron. Fluoride concentration in the groundwater sample of these villages was found to vary between 1.22 to $4.9 \mathrm{mg} / \mathrm{l}$. The high fluoride concentration in the ground water could be a major source of fluoride in water since the geological formation of this area consists of fluorite and Fluor apatite. The population of the study area especially village Hatheda and Dumduma seems to be severely affected by fluorosis. Dental and skeletal fluorosis and deformation of bones especially in adults were observed in the study area which indicates the excess fluoride concentration.
\end{abstract}

Key words: Fluoride, Dental Fluorosis, Skeletal Fluorosis, ground water.

\section{INTRODUCTION}

Water is the precious gift of nature to the mankind and is very essential for the growth and maintenance of the body as it is the important part of all the biological processes. Ground water is the major source of drinking water in the urban as well as rural area. Fluoride $\left(\mathrm{F}^{-}\right)$concentration in water is one of an important aspect which affects the human health. The recommended ${ }^{1}$ concentration of fluoride in drinking water is $1.50 \mathrm{mg} / \mathrm{l}$. Low fluoride content $(<0.60 \mathrm{mg} / \mathrm{l})$ causes dental caries, whereas high $(>1.20 \mathrm{mg} / \mathrm{l})$ fluoride levels results in fluorosis ${ }^{2}$. The bureau of Indian standards $(\mathrm{BIS})^{3}$ prescribed a limit between 1.0 and $1.5 \mathrm{mg} / \mathrm{l}$. The problem of high fluoride concentration is more pronounced in Andhra Pradesh, Bihar, Gujarat, Madhya Pradesh, Punjab, Rajasthan, Tamilnadu and Uttarpradesh. ${ }^{4}$

The disorder of teeth and bones is due to consumption of fluoride rich water ${ }^{5}$. It leads to dental as well as skeletal fluorosis. Dental fluorosis is characterized by permanent yellowish and brown discoloration of teeth. Children are highly susceptible to dental fluorosis. It is irreversible and can't be cured. Skeletal fluorosis affects both young and adults which starts with pain and stiffness of joints and leads to crippling deformities of the spine and major joints. Fluorosis has no treatment and hence is considered to be a deadly disease.

Fluoride in water is mostly of geological origin. The source of fluoride in ground water of the study area is mainly from geological occurrences. The lithological units of the study area consist of Archaen granite, genesis complex rocks, shale and limestone.

Ground water samples were collected from villages of Karera and Narwar blocks of Shivpuri district, Madhya Pradesh, India. The samples are analyzed for fluoride along with other chemical parameters.

\section{MATERIAL AND METHODS}

\section{Profile of study area}

The total area of Shivpuri district is $10278 \mathrm{sq} \mathrm{kms}$. It lies between $24^{\circ} 6^{\prime}-25^{\circ} 6^{\prime}$ North latitude and $77^{\circ} 0^{\prime}-78^{\circ} 4^{\prime}$ East longitude at a M.S.L. height of $521.50 \mathrm{mt}$. It has 7 tehsils and 8 administrative blocks. Total population of the district according to 2011 census is $1,726,050{ }^{6}$ 


\section{Water sampling}

Sampling was done village wise and wherever wells and hand pumps exists in the study area. Samples were collected in the month of May 2015. Samples were collected in clean and sterile one litre polythene cans. Analysis was carried out for $\mathrm{pH}$, Electrical conductivity, Total dissolved solids, Total hardness, total alkalinity, Calcium, Magnesium, chlorides, nitrates and fluoride by following standard techniques (Anonymous, 1976 ) $^{7}$.

\section{OBSERVATION}

Table 1. showing the values of physicochemical parameters including fluoride in the 30 water samples. Highlighted figures show the fluoride content more than the permissible limit.

\begin{tabular}{|c|c|c|c|c|c|c|c|c|c|c|c|}
\hline 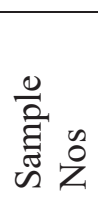 & $\begin{array}{l}\text { Name of } \\
\text { village }\end{array}$ & $\begin{array}{l}\text { TDS } \\
(\mathrm{mg} / \mathrm{l})\end{array}$ & $\mathrm{pH}$ & $\begin{array}{l}\mathrm{EC}(\mu \\
\mathrm{mhos} \\
/ \mathrm{cm})\end{array}$ & $\begin{array}{l}\text { Total } \\
\text { hard } \\
\text { Ness } \\
(\mathrm{mg} / \mathrm{l})\end{array}$ & $\begin{array}{l}\text { Alkalinit } \\
\mathrm{y} \\
(\mathrm{mg} / \mathrm{l})\end{array}$ & $\begin{array}{l}\mathrm{Mg} \\
(\mathrm{mg} / \mathrm{l})\end{array}$ & $\begin{array}{l}\mathrm{Ca} \\
(\mathrm{mg} / 1 \\
)\end{array}$ & $\begin{array}{l}\mathrm{Cl} \\
(\mathrm{mg} / 1 \\
)\end{array}$ & $\begin{array}{l}\text { Nitrate } \\
(\mathrm{mg} / \mathrm{l})\end{array}$ & $\begin{array}{l}\mathrm{F} \\
(\mathrm{mg} / 1 \\
)\end{array}$ \\
\hline 1 & Hatheda & 677 & 8.4 & 897 & 395 & 192 & 40 & 87.5 & 70.5 & 10.1 & 4.51 \\
\hline 2 & Hatheda & 1425 & 8.15 & 1190 & 800 & 186 & 55 & 65 & 124.5 & 15.6 & 4.9 \\
\hline 3 & Hatheda & 762.5 & 8.25 & 1215 & 383.5 & 326.5 & 59.5 & 48 & 79 & 12 & 3.6 \\
\hline 4 & Hatheda & 603.5 & 7.79 & 967 & 314.5 & 219 & 67 & 55.5 & 80.5 & 10.05 & 2.25 \\
\hline 5 & Hatheda & 1136 & 8.17 & 888 & 346.5 & 369 & 81 & 79 & 115.5 & 21 & 3.15 \\
\hline 6 & Bichi & 769 & 8.5 & 913 & 264.5 & 316.5 & 63 & 72 & 78 & 14.35 & 2.62 \\
\hline 7 & Bichi & 728 & 8.67 & 1147 & 291.5 & 320 & 82 & 118.5 & 212.5 & 24.3 & 1.97 \\
\hline 8 & Bichi & 1623 & 8.02 & 2035 & 1088 & 192 & 103 & 197 & 347 & 70.6 & 3.01 \\
\hline 9 & Baroda & 865.5 & 7.73 & 1334 & 425 & 256.5 & 37 & 147 & 163 & 20.2 & 1.7 \\
\hline 10 & Baroda & 703 & 7.9 & 1328 & 400 & 277 & 60 & 126 & 154 & 14.5 & 2.16 \\
\hline 11 & Baroda & 922.5 & 7.57 & 1270 & 435 & 378 & 73 & 119.5 & 76.5 & 40.2 & 1.67 \\
\hline 12 & Phulpur & 2147 & 7.96 & 3480 & 904 & 441 & 124.5 & 130 & 626 & 61.7 & 2.95 \\
\hline 13 & Phulpur & 595.5 & 7.67 & 832 & 406.5 & 276 & 51 & 133 & 67.5 & 13.2 & 2.36 \\
\hline 14 & Phulpur & 1033 & 7.83 & 1181 & 599 & 233 & 102.5 & 114 & 146 & 31.8 & 3.56 \\
\hline 15 & Phulpur & 974 & 8.3 & 1164 & 453 & 324 & 30 & 140.5 & 139 & 31.4 & 2.33 \\
\hline 16 & Dehretasani & 735.5 & 8.0 & 1092 & 366.5 & 297 & 33.5 & 103.5 & 156 & 17.65 & 2 \\
\hline 17 & Dehretasani & 946.5 & 8.4 & 999 & 537 & 218 & 92 & 87 & 89.5 & 57.5 & 1.69 \\
\hline 18 & Dehretasani & 1142 & 8.34 & 1370 & 669.5 & 209.5 & 104.5 & 55.5 & 106 & 53.5 & 1.85 \\
\hline 19 & Dehretasani & 606.5 & 7.28 & 627 & 256.4 & 215 & 33.5 & 121.5 & 149 & 29.5 & 1.26 \\
\hline 20 & Doni & 496 & 8.7 & 628 & 207 & 186 & 42.5 & 72 & 132.5 & 9.4 & 3.4 \\
\hline 21 & Doni & 788.5 & 8.2 & 955 & 273 & 212.5 & 50.5 & 131 & 244 & 27.2 & 2.57 \\
\hline 22 & Doni & 639 & 7.57 & 724 & 400.5 & 176 & 29.5 & 139 & 89 & 25.7 & 2.52 \\
\hline 23 & Gokunda & 817 & 8.59 & 1275 & 348 & 278.5 & 21 & 100.5 & 111.5 & 18.6 & 2.57 \\
\hline 24 & Gokunda & 705.5 & 8 & 1093 & 334 & 279 & 24 & 120.5 & 106.5 & 41.5 & 1.86 \\
\hline 25 & Sehore & 829.5 & 7.99 & 1234 & 402.5 & 352 & 36.7 & 126.5 & 62.6 & 37.1 & 1.64 \\
\hline 26 & Dumduma & 638.5 & 8.05 & 1020 & 377 & 315.5 & 30.7 & 116 & 55.5 & 42.6 & 1.99 \\
\hline 27 & Dumduma & 623 & 7.83 & 737 & 306.5 & 209.5 & 68.5 & 164.4 & 435.5 & 26.5 & 2.12 \\
\hline 28 & Sirsod & 899 & 8.53 & 1308 & 457 & 331.5 & 32.5 & 140.5 & 212.5 & 60.5 & 4.51 \\
\hline 29 & Sirsod & 815.5 & 7.56 & 811 & 344 & 412.5 & 87.5 & 105.5 & 610.5 & 69.5 & 1.66 \\
\hline 30 & $\begin{array}{l}\text { Bichi(from } \\
\text { kanker) }\end{array}$ & 601 & 7.39 & 690.5 & 364 & 169 & 58.5 & 89.5 & 68 & 9.55 & 1.22 \\
\hline
\end{tabular}




\section{RESULT AND DISCUSSION}

The result revealed that fluoride concentration in the study area varied between $1.22 \mathrm{mg} / \mathrm{to} 4.9 \mathrm{mg} / \mathrm{l}$. Out of 30 samples studied, only 2 samples were observed below the permissible limits. All other samples showed higher concentration of fluoride compared to the prescribed permissible values. Maximum fluoride conc. (4.9 mg/l) was observed in Hatheda village, while the minimum value $(1.22 \mathrm{mg} / \mathrm{l})$ was observed from the water that is brought from Kanker village to Phulpur village through pipelines. Village Hatheda (F- conc 4.9mg/l) and Dumduma (Fconcentartion $4.51 \mathrm{mg} / \mathrm{l}$ ), in particular showed higher concentrations of fluoride compared to the other villages studied. The presence of high concentration of fluoride may be due to the geological formation of the area. The rock types - granite and gneisses in this area attribute to the high concentration of fluoride in ground water. A visit to these villages and interaction with the inhabitants proved that the area is affected by dental and skeletal fluorosis. Prominent yellowish to brown patches on the teeth, weakening joints, skeletal deformations were observed in the population.

The results revealed that $\mathrm{pH}$ ranged from (7.28 to 8.59). Minimum $\mathrm{pH}$ (7.28) was observed from Phulpur village and maximum (8.59) was observed from village Hatheda. All the water samples were found to be within limit of $\mathrm{pH}$ but alkaline in nature. According to WHO (1996), the permissible limit for $\mathrm{pH}$ is 6.9 to 9.2. $\mathrm{pH}$ showed a positive correlation with fluoride.

The samples analyzed showed electrical conductivity varying between $627 \mu$ mhos $/ \mathrm{cm}$ to $3480 \mu \mathrm{mhos} / \mathrm{cm}$. All the samples showed values of EC exceeding the permissible limit for drinking water $(300 \mu \mathrm{mhos} / \mathrm{cm})$ as per the ISI standards ${ }^{8}$. Minimum value of EC $(627 \mu \mathrm{mhos} / \mathrm{cm})$ was found in the village Sehore and maximum value of EC (3480 $\mu \mathrm{mhos} / \mathrm{cm})$ was found in village Phulpur.

TDS concentration in the samples studied varied between $595.5 \mathrm{mg} / \mathrm{l}$ and $1425 \mathrm{mg} / \mathrm{l}$. The prescribed permissible limit of TDS for drinking water is $500 \mathrm{mg} / \mathrm{l}^{\mathbf{8}}$. TDS concentration above $500 \mathrm{mg} / \mathrm{l}$ was noticed in most of the samples .Minimum TDS concentration $(595.5 \mathrm{mg} / \mathrm{l})$ was observed from the well of Dumduma village and maximum TDS concentration $(1425 \mathrm{mg} / \mathrm{l})$ was obtained from Phulpur village. Higher concentrations of TDS observed in the ground water samples of the study area may be attributed to granite rocks present in the study area.

All the samples analyzed showed the higher concentrations of total alkalinity exceeding the prescribed permissible limit for drinking water, i.e, $200 \mathrm{mg} / \mathrm{l}^{\mathbf{8}}$. The minimum concentration of total alkalinity $(169 \mathrm{mg} / \mathrm{l})$ was observed in the tap water brought from Kanker in Bichi village while the maximum concentration of alkalinity (441 mg/l) was observed from a well in Phulpur village. Higher concentrations of alkalinity were observed in most of the samples of the study area.

All the samples analyzed showed higher concentration of total hardness to the prescribed limit for drinking water i.e., $200 \mathrm{mg} / \mathrm{l}^{8}$. The maximum hardness $(1086 \mathrm{mg} / \mathrm{l})$ was found from the well of Bichi village and the minimum $(207 \mathrm{mg} / \mathrm{l})$ was found in the well of Dumduma village.

Some of the samples analyzed showed higher concentration of chlorides than the prescribed permissible limit for drinking water i.e., $250 \mathrm{mg} / \mathrm{l}$ 8. The maximum concentration of chlorides $(626 \mathrm{mg} / \mathrm{l})$ was found in the well of Phulpur village and the minimum $(55.5 \mathrm{mg} / \mathrm{l})$ was also found in the well of the same village.

Some of the water samples analyzed showed higher concentration of Nitrates than the prescribed permissible limit for drinking water i.e., $45 \mathrm{mg} / 1$ 8. The maximum concentration of Nitrates $(69.5 \mathrm{mg} / \mathrm{l})$ was observed in the well of Bichi village. The minimum concentration $(9.4 \mathrm{mg} / \mathrm{l})$ was observed in the tap water brought from village Kanker.

The relationship of F- with other geo-chemical parameters is examined by generating correlation matrix. The EC exhibits good positive correlation with TDS and total hardness. An average correlation of electrical conductivity is observed with magnesium and chloride. This is due to the fact that conductivity depends on total dissolved solids 
and main constituents of TDS in water are $\left(\mathrm{Ca}^{2+}, \mathrm{Mg}^{2+}\right.$ and $\left.\mathrm{Cl}^{-}\right)$. A moderate positive correlation of total hardness is observed with magnesium.

Graph showing high Fluoride concentration in the samples studied. The dotted line shows the permissible limit.

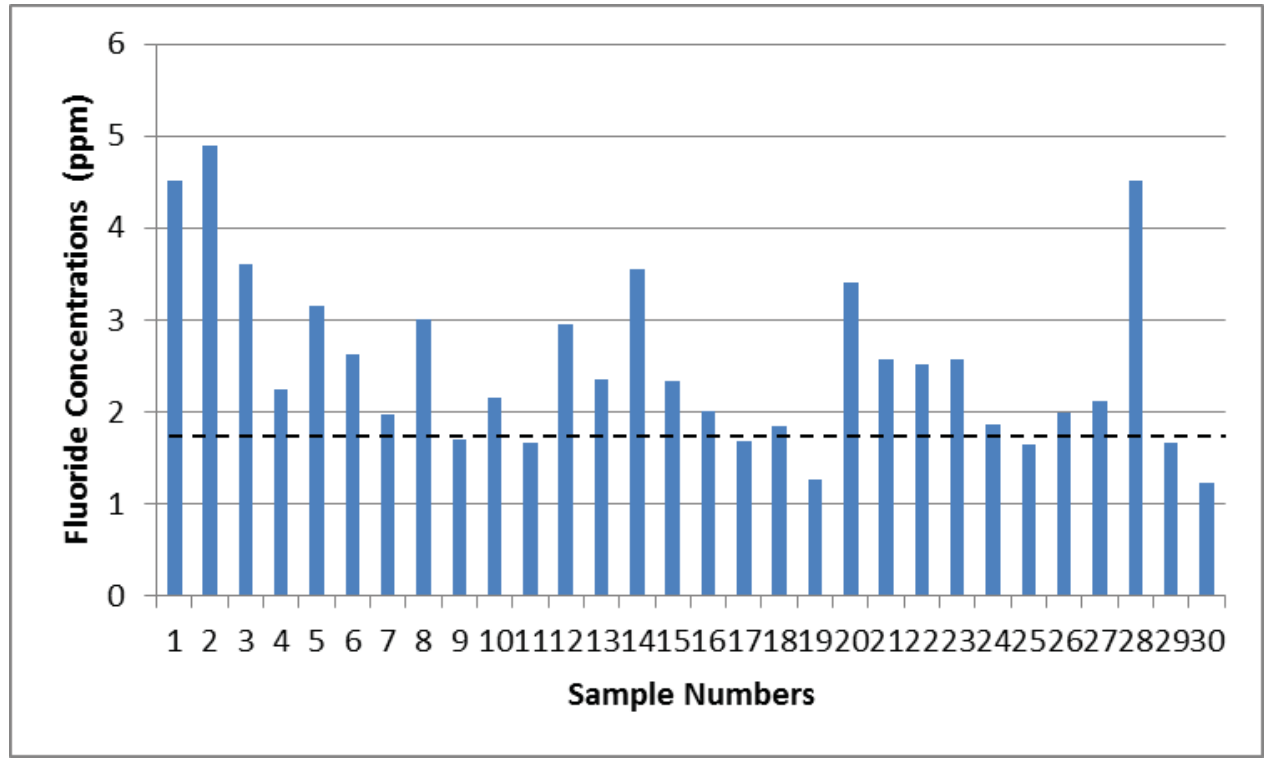

\section{CONCLUSION}

Most of the water samples in the study area evidenced excess fluoride concentration. 28 out of 30 samples studied showed high fluoride concentration. The excess fluoride concentration in the area may be attributed to the geological formation of that particular area and continuous depletion of ground water. The water in the study area is not suitable for domestic consumption without defluoridation. Water harvesting and defluoridation is suggested to combat with the problem.

\section{REFERENCES}

[1] WHO, Guidelines for drinking water quality. World Health Organisation, Geneva, 1984.

[2] ISI, Indian standard specification for drinking water. IS: 10500, Indian Standard Institute, 1983.

[3] BIS, Indian standard specification for drinking water. 10500, Indian Standard Institute, 1991.

[4] Pillai, K.S. and Stanley, V.A., Implications of fluoride -an endless uncertainty.J.Environ.Biol.,2002,23,81-87.

[5] Susheela A.K., Curr.Sci. 1999: 77 (10): 1250.

[6] www.shivpuridistrict.com ( or The Encyclopedic District Gazetteers of India).

[7] Anonymous (1976). Standard methods for examination of water and waste water (14 ${ }^{\text {th }}$ Ed). American public health Association, APHA, AWWA, WPCF, Washington D.C., USA. 